\title{
Evaluation of sorghum grain hydrolysates and dried distillers grains with solubles for the production of microbial transglutaminase
}

\section{G.C. Rodríguez-Castillejos, S.J. Tellez-Luis, M. Vázquez, J.A. Lois-Correa \& J.A. Ramírez}

To cite this article: G.C. Rodríguez-Castillejos, S.J. Tellez-Luis, M. Vázquez, J.A. Lois-Correa \& J.A. Ramírez (2014) Evaluation of sorghum grain hydrolysates and dried distillers grains with solubles for the production of microbial transglutaminase, CyTA - Journal of Food, 12:2, 115-120, DOI: $10.1080 / 19476337.2013 .801520$

To link to this article: https://doi.org/10.1080/19476337.2013.801520

(C) 2013 Taylor \& Francis

Submit your article to this journal

View related articles $\asymp$

Citing articles: 1 View citing articles
Published online: 07 Aug 2013.

Llll Article views: 489

View Crossmark data 


\title{
Evaluation of sorghum grain hydrolysates and dried distillers grains with solubles for the production of microbial transglutaminase
}

\section{Evaluación de hidrolizados de granos de sorgo y granos de destilería secos con solubles para la producción de transglutaminasa microbiana}

\author{
G.C. Rodríguez-Castillejos ${ }^{\mathrm{a}}$, S.J. Tellez-Luis ${ }^{\mathrm{b}}$, M. Vázquez $^{\mathrm{c}}$, J.A. Lois-Correa $^{\mathrm{a}}$ and J.A. Ramírez ${ }^{\mathrm{d} *}$ \\ ${ }^{a}$ Research Center on Applied Sciences and Advanced Technology (CICATA-IPN), National Polytechnic Institute, Altamira, Tamaulipas, \\ Mexico; ${ }^{b}$ Department of Food Science and Technology, U.A.M. Reynosa-Aztlán. Universidad Autónoma de Tamaulipas, Reynosa, \\ Tamaulipas, Mexico; ' Area of Food Technology, Department of Analytical Chemistry, Faculty of Veterinary Science, University of \\ Santiago de Compostela, Campus de Lugo, Lugo, Spain; ${ }^{d}$ Center of Excellence, Universidad Autónoma de Tamaulipas, Ciudad Victoria, \\ Tamaulipas, Mexico
}

(Received 6 September 2012; final version received 29 April 2013)

\begin{abstract}
Sorghum grains can be used as a source of fermentable sugars to reduce the culture media cost for microbial growth of Streptomyces and the production of microbial transglutaminase (MTGase). In the production of ethanol from corn, dried distillers grains with solubles (DDGSs) are generated as waste. The aim of this work is to elucidate the biotechnological production of transglutaminase by Streptomyces mobaraensis NRRL-3191 grown in a medium containing sorghum grains hydrolysates and DDGS is feasible. The results showed that casein has a great effect on the production of MTGase while DDGS did not show any significant effect on the range of study. The model obtained predicts $0.66 \mathrm{U} / \mathrm{mL}$ of MTGase activity using enzymatic hydrolysates of sorghum grains supplemented with yeast extract (2 g/L), DDGS (2 g/L), and casein (19.5 g/L).
\end{abstract}

Keywords: transglutaminase; Streptomyces mobaraensis; sorghum; dried distillers grains with solubles; casein; hydrolysates

\begin{abstract}
Los granos de sorgo se pueden utilizar como fuente de azúcares fermentables para reducir los costes de medios de cultivo para el crecimiento microbiano de Streptomyces y la producción de transglutaminasa microbiana (MTGasa). En la producción de etanol a partir de maíz, se generan como residuos granos de destilería secos con solubles (DDGS). El objetivo de este trabajo fue determinar si la producción biotecnológica de transglutaminasa por Streptomyces mobaraensis NRRL-3191 cultivados en un medio que contiene hidrolizados de granos de sorgo y DDGS es factible. Los resultados mostraron que la caseína tiene un gran efecto en la producción de MTGasa mientras que DDGS no mostraron un efecto significativo en el intervalo de estudio. El modelo obtenido predice $0.66 \mathrm{U} / \mathrm{mL}$ de actividad MTGase usando hidrolizados enzimáticos de granos de sorgo suplementados con extracto de levadura (2 g/L), DDGS (2 g/L) y caseína (19,5 g/L).
\end{abstract}

Palabras claves: transglutaminasa; Streptomyces mobaraensis; sorgo; granos de destilería secos con solubles; caseina; hidrolizados

\section{Introduction}

Transglutaminases (TGases; EC 2.3.2.13; protein-glutamine $y$ glutamiyltransferase) are a family of enzymes that catalyzes an acyl transfer reaction between the $\gamma$-carboxyamide group of a peptide-bound glutaminyl residue (acyl donors) and a variety of primary amines (acyl acceptors), including the amino group of lysine (Yokoyama, Nio, \& Kikuchi, 2004). TGases have been found in animal tissues and body fluids, fish, plants, and microorganisms (Ando et al., 1989; Falcone, Serafini-Fracassini, \& del Duca, 1993; Folk, 1980; Lilley, Skill, Griffin, \& Bonner, 1998; Yasueda et al., 1995). In food processing, this enzyme has been used to promote polymerization of proteins, texture improvement, meat restructuring, gel formation, and to increase nutritional value of proteins as well (Alves-Macedo, Duraes, \& Hurami, 2007; Griffin, Casadio, \& Bergamini, 2002; Motoki \& Seguro, 1998). The cross-linked products are highly resistant to mechanical challenge and proteolytic degradation (Andrés-Bello, García-Segovia, Ramírez, \& Martínez-Monzó, 2011; Griffin et al., 2002). The first experiments to improve food properties with TGase were performed in 1980; the studies showed that several food compounds, such as casein and soy proteins, were good substrates for mammalian TGase (Ikura, Kometani, Yoshikawa, Sasaki, \& Chiba, 1980; Motoki, Nio, \& Takinami, 1984).

Mammalian TGases are $\mathrm{Ca}^{2+}$-dependent. The relatively small quantities obtained from mammalian sources and the high costs of production have limited the use of TGase in food industry. For this reason, several studies were conducted to search the ways to produce TGases by microorganisms. Ando et al. (1989) isolated about 5000 strains from soil and investigated hydroxamate-forming activity; strong enzyme activity being found in an actinomycetes strain (Streptoverticillium S-8112). Other Streptoverticillium strains, such as Streptoverticillium griseocarneum, Streptoverticillium cinnamoneum, and Streptoverticillium mobaraense, also have the ability to produce microbial transglutaminase (MTGase; de Jong \& Koppelman, 2002; Motoki, 1989). Many species of Streptoverticillium have been renamed as Streptomyces (Kampfer, Kroppenstedt, \& Dott, 1991).

The use of MTGase in food processing is increasing as MTGase is $\mathrm{Ca}^{2+}$ independent. This fact may make this enzyme adequate for the food industry. 
MTGases have been reported as cross-linker to cross-link myofibrillar proteins, gelatin, milk proteins, soy proteins, egg yolk and white, fish proteins, meat proteins, and cereal proteins (Broderick et al., 2005; Jaros, Partschefeld, Henle, \& Rohm, 2006). The modification of proteins by MTGase improves rheological properties. It can be used for the encapsulation of lipids or lipid-soluble materials, or to improve gel formation and gel properties (Jaros et al., 2006; Kuraishi et al., 1997; Wang, Yu, \& Wei 2012).

MTGase has also shown to have the potential to be used in the textile industry. Functional molecules have been grafted onto wool fibers. The enzyme has also shown to remediate the damage caused by chemical and proteases during wool processing and washing of wool fabrics (Cortez \& Bonner, 2004).

The fermentation procedures and fermentative media composition for MTGase production are similar for some microorganisms studied by Ando et al. (1989) and Motoki (1989). As a carbon source, they can be used as glucose, sucrose, starch, glycerol, xylose, and dextrin. Nitrogen sources can be urea, flour of soya, rice, maize, wheat, bran, soybean, corn steep liquid, peptone, yeast extract, meat extract, casein, $\mathrm{NH}_{4} \mathrm{NO}_{3}$, $\left(\mathrm{NH}_{4}\right)_{2} \mathrm{SO}_{4}, \mathrm{NaNO}_{3}$, and $\mathrm{NH}_{4} \mathrm{Cl}$. Minerals and trace elements are also necessary (Alves-Macedo et al., 2007; Portilla-Rivera, Telléz-Luis, Ramírez, \& Vázquez, 2009; Téllez-Luis, Ramírez \& Vázquez, 2004). The submerged cultivation of Streptomyces $s p$ is aerobic and the agitation is needed. The optimum growth temperature varying between $25^{\circ} \mathrm{C}$ and $33^{\circ} \mathrm{C}$ (Nagy \& Szakacs, 2008; Sarafeddinov, Arif, Peters, \& Fuchsbauer, 2011).

The formulation of fermentative media is important because the composition is an important factor for production, yield, and volumetric productivity of enzyme (Guerra-Rodríguez \& Vázquez, 2013). But in industrial biotechnological processes, the culture media represent a high cost; for this, it is important to find alternatives to reduce the cost of the medium and consequently the overall cost of the process. In MTGase case, the cost of fermentation media can represent almost $30 \%$ of the total costs (Téllez-Luis, González-Cabriales, Ramírez \& Vázquez, 2004; Téllez-Luis, Ramírez, et al., 2004). The industrial media are not economically attractive because the high amount of expensive nutrients such as yeast extract or peptone. Some research works have tried to use economical raw material such as agriculture waste or by-products. These can be used as a carbon source for the culture media. Téllez-Luis, GonzálezCabriales, et al. (2004) studied MTGase production on hydrolysates of sorghum straw, obtaining up to $0.348 \mathrm{U} / \mathrm{mL}$. Sugarcane molasses can also be used as a carbon source. It can be used to obtain a TGase activity up to $0.240 \mathrm{U} / \mathrm{mL}$ (PortillaRivera et al., 2009).

In Mexico, sorghum is used mainly as livestock feed. The cost of this grain is relatively low and its use to obtain fermentable sugars for microbial growth of MTGase could be to reduce the cost of the fermentative medium.

In the production of ethanol from corn, dried distillers grains with solubles (DDGSs) are generated as waste. The aim of this work is to study the possibilities for the production of TGase by a selected Streptomyces mobaraensis strain grown in a medium based on enzymatic sorghum grain hydrolysates and DDGS. Additionally, the effect of supplementing with different concentrations of casein, yeast extract, and DDGS has been also studied.

\section{Material and methods \\ Raw material and microorganism}

Sorghum grains were obtained from a local factory (Reynosa, Tamaulipas, Mexico). DDGS was donated by Lincolnland AgriEnergy (Palestine, IL, USA). Freeze-dried broths of wild $S$. mobaraensis (formerly S. ladakanum) NRRL-3191 strain were obtained from Agricultural Research Service Culture Collection (Peoria, IL, USA). Pure cultures were maintained on agar plates at $4^{\circ} \mathrm{C}$ and transferred monthly.

\section{Media preparation}

Enzymatic hydrolysates of sorghum grains were performed under conditions selected previously, using amylase $(0.66 \mathrm{~mL} /$ $\mathrm{L})$ and glucoamylase $(0.66 \mathrm{~mL} / \mathrm{L})$, and by incubation for $1 \mathrm{~h}$ at $65^{\circ} \mathrm{C}$ with an agitation speed of $150 \mathrm{rpm}$.

Fermentative culture media were prepared using sorghum grain hydrolysates containing glucose $(30 \mathrm{~g} / \mathrm{L})$ and supplemented with peptone $(10.5 \mathrm{~g} / \mathrm{L}), \mathrm{Na}_{2} \mathrm{HPO}_{4}(5 \mathrm{~g} / \mathrm{L}), \mathrm{KH}_{2} \mathrm{PO}_{4}(2 \mathrm{~g} / \mathrm{L})$, and $\mathrm{MgSO}_{4}(0.5 \mathrm{~g} / \mathrm{L})$. Several concentrations of sodium casein $(0,15$, or $30 \mathrm{~g} / \mathrm{L})$, yeast extract $(2,6$ or, $10 \mathrm{~g} / \mathrm{L})$, and DDGS $(2,6$ or, $10 \mathrm{~g} / \mathrm{L}$ ) were evaluated to complete the media composition. The hydrolysates were sterilized by separating rest of the medium compounds to avoid Maillard reactions. Then, they were mixed in sterile conditions. Figure 1 shows the overall idea of the proposed process.

Experiments were carried out for $120 \mathrm{~h}$ at $26^{\circ} \mathrm{C}$ in the orbital shakers (agitation speed $250 \mathrm{rpm}$ ) using 250-mL Erlenmeyer flasks filled with $100 \mathrm{~mL}$ of culture medium.

\section{Analytical methods}

Samples were withdrawn from the submerged cultivation at 72 , 96, and $120 \mathrm{~h}$ and centrifuged $(10 \mathrm{~min}, 4500 \times \mathrm{g})$. In the

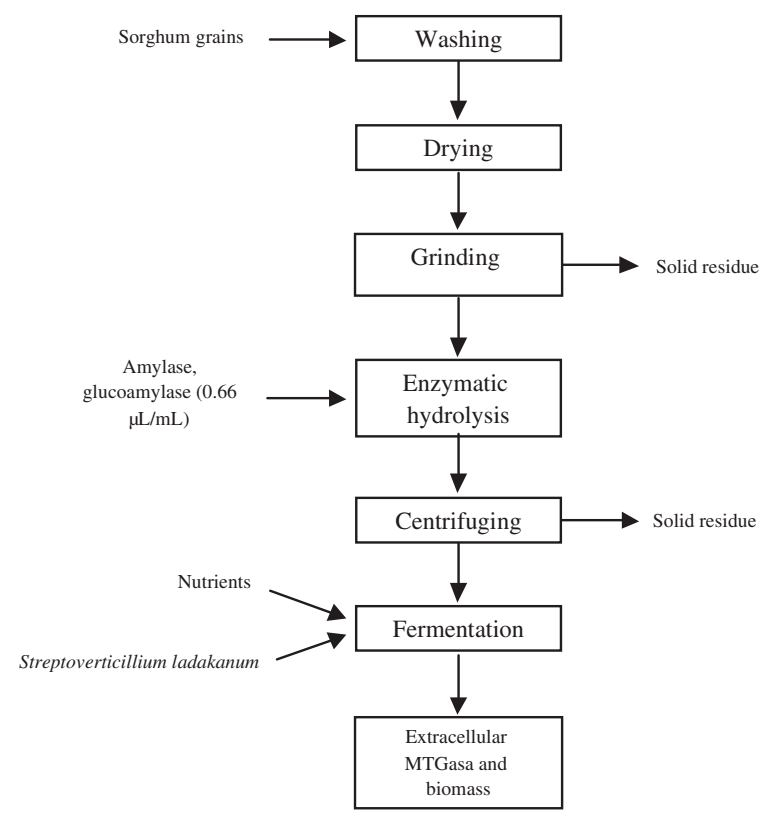

Figure 1. General idea concerning the studied process.

Figura 1. Idea general relativa al proceso estudiado. 
supernatant, glucose was analyzed by High-performance liquid chromatography (HPLC). This analysis was carried out using a ION-300 column (Transgenomic Inc., Omaha, NE, USA; oven temperature, $45^{\circ} \mathrm{C}$ ) with isocratic elution (flow rate, $0.4 \mathrm{~mL} / \mathrm{min}$; mobile phase, $0.0025 \mathrm{M} \mathrm{H}_{2} \mathrm{SO}_{4}$ ) and a refraction index detector. Extracellular TGase activity was measured by a colorimetric method based on the formation of hydroxamate from $N$-carbobenzoxy- $\delta$-glutaminylglycine. One unit of activity was defined as the amount of enzyme that causes the formation of 1 $\mu \mathrm{mol}$ of hydrozamate in $1 \mathrm{~min}$ at $37^{\circ} \mathrm{C}$ (Grossowicz, Wainfan, Borek, \& Waelsch, 1950).

\section{Modeling and statistical analysis}

The experimental design was analyzed applying the Design Expert ${ }^{\circledR} 7.11$ software (Stat-Ease, Inc., Minneapolis, MN, USA). The set of experiments followed the Box-Behnken design. This kind of response surface design formed by combining the two levels factorial designs with incomplete block designs creating designs with desirable statistical properties but with only a fraction of the experiments required for a three-level factorial (Box \& Behnken, 1960; Don, Xie, Wang, Zhan, \& Yao, 2009).

\section{Results and discussion}

\section{Preliminary experiments}

The glucose concentration of enzymatic sorghum grain hydrolysates was $62 \mathrm{~g} / \mathrm{L}$. They were diluted with distilled water because the experiments were carried out with the expectation of an initial concentration of approximately $30 \mathrm{~g} / \mathrm{L}$. Based on previous works, fermentations were carried out in shaker with an agitation speed of $250 \mathrm{rpm}$ at $28^{\circ} \mathrm{C}$ for 5 days (Portilla-Rivera et al., 2009; Téllez-Luis, González-Cabriales, et al., 2004; Téllez-Luis, Ramírez, et al., 2004).

For comparative purpose, a set of three fermentations were carried out containing as a carbon source such as (1) enzymatic hydrolysis of sorghum grain (containing $30 \mathrm{~g} / \mathrm{L}$ of glucose); (2) glycerol (30 g/L); and (3) a mixture of enzymatic hydrolysis of sorghum grain and glycerol ( $15 \mathrm{~g} / \mathrm{L}$ each one). The mineral and nitrogen content was the same in the three culture media (peptone $(10.5 \mathrm{~g} / \mathrm{L}) ; \mathrm{Na}_{2} \mathrm{HPO}_{4}(5 \mathrm{~g} / \mathrm{L}) ; \mathrm{KH}_{2} \mathrm{PO}_{4}(2 \mathrm{~g} / \mathrm{L}) ; \mathrm{MgSO}_{4}(0.5$ $\mathrm{g} / \mathrm{L})$; yeast extract $(2.5 \mathrm{~g} / \mathrm{L})$; casein $(35 \mathrm{~g} / \mathrm{L}))$.

The growth of $S$. mobaraensis NRRL-3191 in the three media was the same. At $96 \mathrm{~h}$, only residual glucose $(3.5 \mathrm{~g} / \mathrm{L})$ was detected. The highest extracellular TGase activity was obtained in the medium of glycerol, $0.4 \mathrm{U} / \mathrm{mL}$ at $96 \mathrm{~h}$. The highest activity in media containing enzymatic hydrolysis of

Table 1. Results of transglutaminase activity $(\mathrm{U} / \mathrm{mL})$ obtained in the preliminary experiments.

Tabla 1. Resultados de actividad transglutaminásica $(\mathrm{U} / \mathrm{mL})$ obtenida en los experimentos preliminares.

\begin{tabular}{lccc}
\hline $\begin{array}{l}\text { Fermentation } \\
\text { time (h) }\end{array}$ & $\begin{array}{c}\text { Sorghum grain } \\
\text { hydrolysates }\end{array}$ & $\begin{array}{c}\text { Mixture of sorghum grain } \\
\text { hydrolysates and glycerol }\end{array}$ & Glycerol \\
\hline 72 & 0.18 & 0.13 & 0.2 \\
96 & 0.34 & 0.34 & 0.4 \\
120 & 0.26 & 0.23 & 0.3 \\
144 & 0.23 & 0.2 & 0.3 \\
\hline
\end{tabular}

sorghum and the mixture enzymatic hydrolysis of sorghum-glycerol was $0.34 \mathrm{U} / \mathrm{mL}$ at $96 \mathrm{~h}$ (Table 1 ).

\section{Response surface model}

The influence of casein, DDGS, and yeast extract was determined using the response surface methodology (RSM), which has been used to optimize biochemical and biotechnological processes (Delgado, Castro, \& Vázquez, 2009). The fractional factorial design is especially suitable to account the interactions and identifies the most significant components in the culture medium. Combinations of factors generating a certain optimal response can be identified through factorial design and the use of RSM. The use of these models allows predicting the results that can be obtained under operational conditions, which were not experimentally studied. The obtained parameters also help to understand the overall process. The set of experiments followed a Box-Behnken experimental design (Box \& Behnken, 1960). Using three factors and three levels coded as $-1,0$, and +1 ; and casein, yeast extract, and DDGS were considered as operational variables and their effects on the selected dependent variable (MTGase activity) were determined. Table 2 summarizes the variables involved in the experimental design for the production of extracellular MTGase using sorghum grain hydrolysates.

The inter-relationship between operational and dependent variables can be established through an equation including linear, interaction, and second-order terms. The mathematical model used as first approach was a model of second order as follows:

Table 2. Variables involved in the experimental design for the production of MTGase using sorghum hydrolysates.

Tabla 2. Variables involucradas en el diseño experimental para la producción de MTGase usando hidrolizados de sorgos.

\begin{tabular}{|c|c|c|c|}
\hline & Nomenclature & Units & $\begin{array}{c}\text { Variation } \\
\text { levels }\end{array}$ \\
\hline \multicolumn{4}{|l|}{ (a) Fixed variables } \\
\hline Agitation & & $\mathrm{rpm}$ & 250 \\
\hline Fermentation time & $\mathrm{t}$ & $\mathrm{h}$ & 96 \\
\hline Temperature & $\mathrm{T}$ & ${ }^{\circ} \mathrm{C}$ & 28 \\
\hline Peptone concentration & & $\mathrm{g} / \mathrm{L}$ & 10.5 \\
\hline Magnesium sulfate & $\mathrm{MgSO}_{4}$ & $\mathrm{~g} / \mathrm{L}$ & 0.5 \\
\hline $\begin{array}{l}\text { Monobasic potassium } \\
\text { phosphate }\end{array}$ & $\mathrm{KH}_{2} \mathrm{PO}_{4}$ & $\mathrm{~g} / \mathrm{L}$ & 2.0 \\
\hline Dibasic sodium phosphate & $\mathrm{Na}_{2} \mathrm{HPO}_{4}$ & $\mathrm{~g} / \mathrm{L}$ & 5.0 \\
\hline $\begin{array}{l}\text { Glucose } \\
\text { (b) Independent variables } \\
\text { (factors) }\end{array}$ & Glu & $\mathrm{g} / \mathrm{L}$ & 30 \\
\hline Casein & & $\mathrm{g} / \mathrm{L}$ & $0,15,30$ \\
\hline Yeast extract & & $\mathrm{g} / \mathrm{L}$ & $2,6,10$ \\
\hline $\begin{array}{l}\text { Corn dried distillers grains } \\
\text { with solubles } \\
\text { (c) Dimensionless, } \\
\text { normalized independent } \\
\text { variables }\end{array}$ & DDGS & $\mathrm{g} / \mathrm{L}$ & $2,6,10$ \\
\hline Yeast extract & $x_{1}$ & Dimensionless & $-1,0,1$ \\
\hline $\begin{array}{l}\text { Corn dried distillers grains } \\
\text { with solubles }\end{array}$ & $x_{2}$ & Dimensionless & $-1,0,1$ \\
\hline $\begin{array}{l}\text { Casein } \\
\text { (d) Dependent variable } \\
\text { (response) }\end{array}$ & $x_{3}$ & Dimensionless & $-1,0,-1$ \\
\hline MTG activity & $\mathrm{Y}$ & $\mathrm{U}$ & \\
\hline
\end{tabular}




$$
\mathrm{TGh}=a_{0}+\sum_{i} a_{i} x_{i}+\sum_{i} b_{i} x_{i}^{2}+\sum_{i} \sum_{j} c_{i j} x_{i} x_{i}
$$

where TGh is extracellular TGase activity obtained after $h \mathrm{~h}$ of fermentation; $x_{i}$ are the normalized dimensionless variables $\left(x_{1}, x_{2}, x_{3}\right)$; and $a_{0}, a_{i}, b_{i}$, and $C_{i j}$ are regression coefficients calculated fitting the experimental data by multiple regression. Partial models of the quadratic model were also fitted.

The tested operational conditions (in terms of dimensional and dimensionless operational variables) as well as the experimental results for extracellular MTGase activity are shown in Table 3.

The highest extracellular TGase activity $(0.81 \mathrm{U} / \mathrm{mL})$ was obtained after $96 \mathrm{~h}$ of submerged cultivation in media containing yeast extract $(10 \mathrm{~g} / \mathrm{L})$, DDGS $(6 \mathrm{~g} / \mathrm{L})$, and casein $(30 \mathrm{~g} / \mathrm{L})$. The lowest TGase activity $(0.023 \mathrm{U} / \mathrm{mL})$ was obtained in media without casein, containing exclusively yeast extract (10 $\mathrm{g} / \mathrm{L})$ and DDGS (6 $\mathrm{g} / \mathrm{L})$. This result agrees with previous works

Table 3. Experimental design Box-Behnken with three factors and three levels and results of MTGase activity obtained at $96 \mathrm{~h}$ of fermentation.

Tabla 3. Diseño Box-Behnken experimental con tres factores y tres niveles y resultados de actividad MTGase obtenidos a las $96 \mathrm{~h}$ de fermentación.

\begin{tabular}{lcccrrrr}
\hline & $\begin{array}{c}\text { Yeast extract } \\
(\mathrm{g} / \mathrm{L})\end{array}$ & $\begin{array}{c}\text { DDGS } \\
(\mathrm{g} / \mathrm{L})\end{array}$ & $\begin{array}{c}\text { Casein } \\
(\text { Casein })\end{array}$ & $x_{1}$ & 2 & $x_{3}$ & $\begin{array}{c}\text { MTGase activity } \\
(\mathrm{U} / \mathrm{mL})\end{array}$ \\
\hline 1 & 6.0 & 2.0 & 30.0 & 0 & -1 & 1 & 0.62 \\
2 & 2.0 & 6.0 & 30.0 & -1 & 0 & 1 & 0.54 \\
3 & 10.0 & 10.0 & 15.0 & 1 & 1 & 0 & 0.57 \\
4 & 10.0 & 6.0 & 30.0 & 1 & 0 & 1 & 0.80 \\
5 & 10.0 & 6.0 & 0.0 & 1 & 0 & -1 & 0.023 \\
6 & 2.0 & 10.0 & 15.0 & -1 & 1 & 0 & 0.60 \\
7 & 6.0 & 6.0 & 15.0 & 0 & 0 & 0 & 0.78 \\
8 & 6.0 & 2.0 & 15.0 & 0 & -1 & 0 & 0.52 \\
9 & 10.0 & 2.0 & 15.0 & 1 & -1 & 0 & 0.50 \\
10 & 2.0 & 6.0 & 0.0 & -1 & 0 & -1 & 0.19 \\
11 & 6.0 & 10.0 & 0.0 & 0 & 1 & -1 & 0.10 \\
12 & 6.0 & 2.0 & 0.0 & 0 & -1 & -1 & 0.09 \\
13 & 2.0 & 2.0 & 15.0 & -1 & -1 & 0 & 0.62 \\
14 & 6.0 & 6.0 & 15.0 & 0 & 0 & 0 & 0.79 \\
15 & 6.0 & 6.0 & 15.0 & 0 & 0 & 0 & 0.69 \\
\hline
\end{tabular}

where casein was a TGase production inductor (Portilla-Rivera et al., 2009).

The mathematical model was selected by analyzing the sequential model sum of squares for the partial and complete models. In this case, data fitted well to a quadratic model since this is the highest order polynomial where the additional terms are significant $(P$-value $<0.05)$.

Table 4 shows the analysis of variance (ANOVA) for quadratic model. $F$-value of 20.98 implies that the model was significant; $P$-value of 0.0019 implies that the model terms were significant. The model terms $x_{3}, x_{1}, x_{3}$, and $x_{1}^{2}$ were significant as their $P$-values were less than 0.05 . This implied that casein showed a great impact on the production of MTGase, whereas DDGS did not.

The value of $r^{2}$ for the regression was 0.9742 . This parameter is normally used to determine the correlation of a model. The predicted $r^{2}$ is a measure of the amount of variation in the new data explained by the model. The predicted $r^{2}$ obtained $(0.4765)$ is not in reasonable agreement with the adjusted $r^{2}$ obtained (0.9277). The difference between predicted $r^{2}$ and the adjusted $r^{2}$ should be less than 0.20 units; otherwise, it may be a problem either with the data or with the model.

Another statistical measurement is the "adequate precision," which relates the signal-to-noise ratio. A signal-to-noise ratio of more than 4 is desirable, and the obtained "adequate precision" (13.37) indicates an adequate signal. Considering the above analysis, a model reduction was carried out to improve the model fitting. The term $x_{2}$, the interactions $x_{1} \cdot x_{2}, x_{2} \cdot x_{3}$, and the quadratic term $x_{2}$ were deleted to improve the robustness of the model.

Table 5 showed the coefficients calculated by ANOVA for the reduced model. The $F$-value increased to 25.20 , the $P$-value was also lower than 0.0001 . In this case, casein and casein-yeast extract interaction were significant in the model, while yeast extract was not significant. The "Lack of Fit $F$-value" of 3.43 implies the lack of fit is not significant relative to the pure error (nonsignificant lack of fit is good). The value $r^{2}$ was 0.9098 . The predicted $r^{2}$ of 0.8286 was in reasonable agreement with the adjusted $r^{2}$ of 0.8737 . Moreover, other improvement was the increase in the value of "adequate precision" (14.19) since it was higher in comparison with the value of 13.3 for the complete model.

Table 4. Analysis of variance (ANOVA) for quadratic model.

Tabla 4. Análisis de varianza (ANOVA) para el modelo cuadrático.

\begin{tabular}{|c|c|c|c|c|c|}
\hline Source & Sum of squares & df & Mean square & $F$-Value & $P$-Value $>F$ \\
\hline Model & 0.9639717 & 9 & 0.1071080 & 20.98 & 0.0019 \\
\hline A-Yeast Extract & 0.0004500 & 1 & 0.0004500 & 0.09 & 0.7785 \\
\hline B-DDGS & 0.0038035 & 1 & 0.0038035 & 0.75 & 0.4275 \\
\hline C-Casein & 0.4181333 & 1 & 0.4181333 & 81.92 & 0.0003 \\
\hline $\mathrm{AB}$ & 0.0025000 & 1 & 0.0025000 & 0.49 & 0.5152 \\
\hline $\mathrm{AC}$ & 0.0484000 & 1 & 0.0484000 & 9.48 & 0.0275 \\
\hline $\mathrm{BC}$ & 0.0002000 & 1 & 0.0002000 & 0.04 & 0.8509 \\
\hline $\mathrm{A}^{\wedge} 2$ & 0.0149477 & 1 & 0.0149477 & 2.93 & 0.1477 \\
\hline $\mathrm{B}^{\wedge} 2$ & 0.0343478 & 1 & 0.0343478 & 6.73 & 0.0486 \\
\hline $\mathrm{C}^{\wedge} 2$ & 0.2274052 & 1 & 0.2274052 & 44.55 & 0.0011 \\
\hline Residual & 0.0255216 & 5 & 0.0051043 & & \\
\hline Lack of fit & 0.0194550 & 3 & 0.0064850 & 2.14 & 0.3344 \\
\hline Pure error & 0.0060667 & 2 & 0.0030333 & & \\
\hline Cor total & 0.9894933 & 14 & & & \\
\hline
\end{tabular}

Note: df, degree of freedom. 
Table 5. Analysis of variance (ANOVA) for reduced quadratic model. Tabla 5. Análisis de varianza (ANOVA) para el modelo cuadrático reducido.

\begin{tabular}{lcrcrr}
\hline Source & $\begin{array}{c}\text { Sum } \\
\text { squares }\end{array}$ & df & $\begin{array}{c}\text { Mean } \\
\text { square }\end{array}$ & $F$-Value & $\begin{array}{c}P \text {-Value }> \\
F\end{array}$ \\
\hline Model & 0.900202 & 4 & 0.22505 & 25.20397 & $<0.0001$ \\
A-Yeast & 0.000450 & 1 & 0.00045 & 0.05040 & 0.8269 \\
$\quad$ Extract & & & & & \\
C-Casein & 0.526458 & 1 & 0.52646 & 58.95940 & $<0.0001$ \\
AC & 0.048400 & 1 & 0.04840 & 5.42044 & 0.0422 \\
C^2 & 0.240878 & 1 & 0.24088 & 26.97649 & 0.0004 \\
Residual & 0.089292 & 10 & 0.00893 & & \\
Lack of fit & 0.083225 & 8 & 0.01040 & 3.42960 & 0.2453 \\
Pure error & 0.006067 & 2 & 0.00303 & & \\
Cor total & 0.989493 & 14 & & & \\
\hline
\end{tabular}

Note: df, degree of freedom.

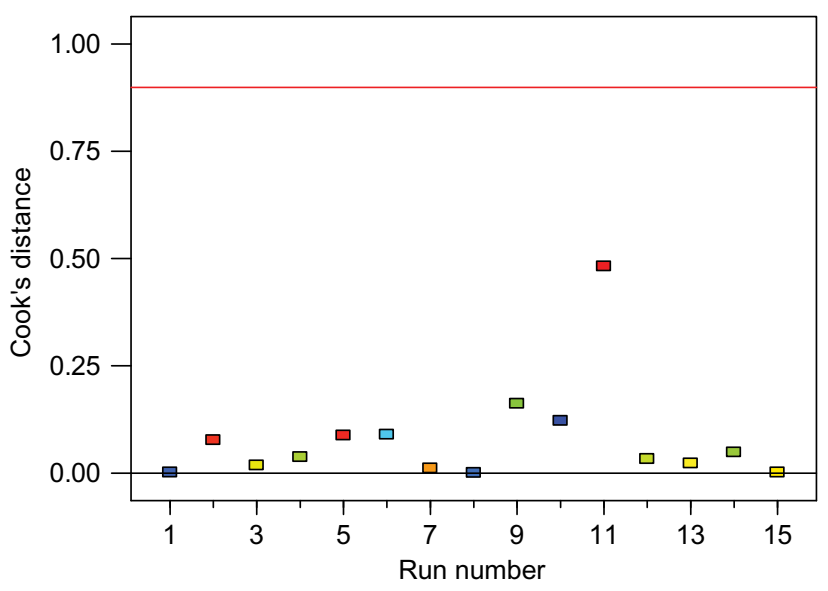

Figure 2. Cook's distance for the case of the model.

Figura 2. Distancia de cook para el caso del modelo.

The reduced mathematical model for TGase activity as function of the actual or dimensional variables used for the new fitting was

$$
\begin{aligned}
\mathrm{TG}= & 0.2787-0.0294 Y E+0.041 S C \\
& -1.833 Y E \cdot S C-1.135 S C^{2}
\end{aligned}
$$

The Cook's distance is a measure of how much the regression changes if a sample is deleted; relatively large values are associated with cases with high leverage and large studentized residuals. Large values should be investigated because they could be caused by recording errors, an incorrect model, or a design point far from the remaining cases. "Large" is defined as a point that is $2-3$ times larger than the other points. Figure 2 shows Cook's distance for the reduced model. It can be seen that it allows observing that it is not necessary to delete observed values to improve the fitting since no case is over the dot line (23 times larger than mean). It confirms that the mathematical model predicts the TGase activity with a good precision.

Figure 3 shows the TGase activity predicted by the reduced model as function of the casein and yeast extract concentration. The conditions to obtain the optimum composition of the fermentative medium were as follows: DDGS ( $2 \mathrm{~g} / \mathrm{L})$; yeast extract $(2 \mathrm{~g} / \mathrm{L})$, and

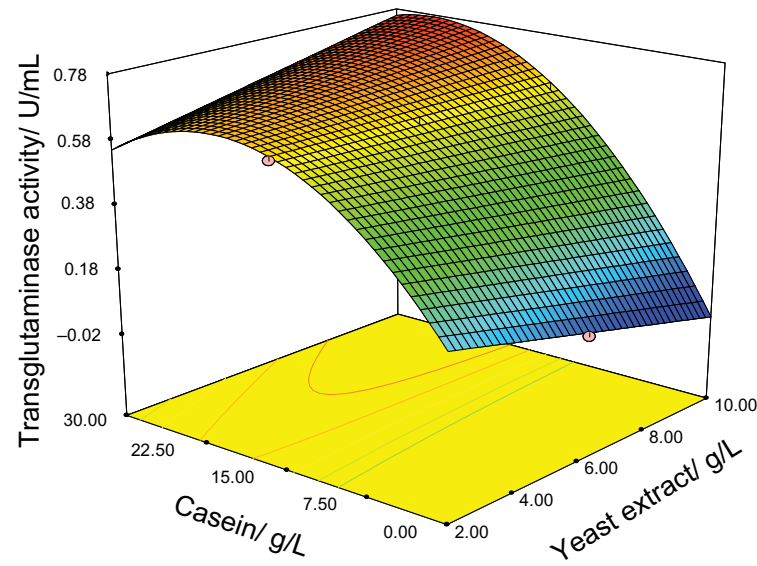

Figure 3. Response surface predicted by the model for MTGase activity.

Figura 3. Superficie de respuesta predicha por el model para la actividad MTGase.

casein $(15 \mathrm{~g} / \mathrm{L})$. Using this formulation, the MTGase activity predicted was $0.67 \mathrm{U} / \mathrm{mL}$. A triplicate confirmatory experiment with this composition gave an activity of $0.62 \mathrm{U} / \mathrm{mL}$, indicating that the model is accuracy.

Junqua, Duran, Gañiste, \& Goulas (1997) recommended $38.4 \mathrm{~g} / \mathrm{L}$ of casein to obtain $0.33 \mathrm{U} / \mathrm{mL}$. Telléz-Luis et al. (2004) studied three casein levels $(20,40$, and $60 \mathrm{~g} / \mathrm{L})$ for MTGase production. Their study predicted a maximum MTGase activity $(0.73 \mathrm{U} / \mathrm{mL})$ with casein $20 \mathrm{~g} / \mathrm{L}$ and $50.5 \mathrm{~g} / \mathrm{L}$ glycerol. Our study shows that cost of media can decrease using a lower casein concentration $(15 \mathrm{~g} / \mathrm{L})$ and an economic carbon source obtained from sorghum grain hydrolysates supplemented with DDGS.

\section{Conclusions}

The results showed that the casein has a great effect on the production of MTGase. DDGS did not show any significant effect on the range of study. A yeast extract-casein interaction was observed. It was possible to design a culture media based on sorghum grain hydrolysates supplemented with yeast extract, DDGS, and casein.

\section{Acknowledgments}

A scholarship from CONACyT and IPN (Mexico) to G. C. Rodríguez-Castillejos is gratefully acknowledged. The authors are grateful for the financial support from the co-ordinator of Fundación Produce A.C.

\section{References}

Alves-Macedo, J., Duraes, L., \& Hurami, H. (2007). Optimization of medium composition for transglutaminase production by a Brazilian soil Streptomyces sp. Electronic Journal of Biotechnology, 4, 618-626.

Ando, H., Adachi, M., Umeda, K., Matsuura, A., Nonaka, M., Uchio, R., ... Motoki, M. (1989). Purification and characteristics of a novel transglutaminase derived from microorganisms. Agricultural and Biological Chemistry, 53, 2613-2617.

Andrés-Bello, A., García-Segovia, P., Ramírez, J. A., \& MartínezMonzó, J. (2011). Production of cold-setting restructured fish products from gilthead sea bream (Sparus aurata) using microbial 
transglutaminase and regular and low-salt level. Cyta-Journal of Food, 9, 121-125.

Box, G., \& Behnken, D. (1960). Some new three level designs for the study of quantitative variables. Technometrics, 2, 455-475.

Broderick, E. P., O'Halloran, D. M., Rotchev, Y. A., Griffin, M., Collighan, R. J., \& Pandit, A. S. (2005). Enzymatic stabilization of gelatin-based scaffolds. Journal of Biomedical Materials Research Part B: Applied Biomaterials, 15, 37-42.

Cortez, J., \& Bonner, P. L. R. (2004). Application of transglutaminase in the modification of wool textiles. Enzyme and Microbial Technology, $34,64-72$.

de Jong, G. A. H., \& Koppelman, S. J. (2002). Transglutaminase catalyzed reactions: Impact on food applications. Journal of Food Science, 67, 2798-2806.

Delgado, R., Castro, A. J., \& Vázquez, M. (2009). Kinetic assessment of the enzymatic hydrolysis of potato (Solanum tuberosum). LWT Food Science and Technology, 42, 797-804.

Don, C. H., Xie, X. Q., Wang, X. L., Zhan, Y., \& Yao, Y. J. (2009). Application of Box-Behnken design in optimisation for polysaccharides extraction from cultured mycelium of Cordyceps sinensis. Food and Bioproducts Processing, 87, 139-144.

Falcone, P., Serafini-Fracassini, D., \& del Duca, S. (1993). Comparative studies of transglutaminase activity and substrates in different organs of Helianthus tuberosus. Journal of Plant Physiology, 142, 265-273.

Folk, J. E. (1980). Transglutaminases. Annual Review of Biochemistry, $49,517-531$.

Griffin, M., Casadio, R., \& Bergamini, C. M. (2002). Transglutaminases: Nature's biological glues. Biochemical Journal, 368, 377-396.

Grossowicz, N., Wainfan, E., Borek, E., \& Waelsch, H. (1950). The enzymatic formation of hydroxamic acids from glutamine and asparagine. Journal of Biological Chemistry, 187, 111-125.

Guerra-Rodríguez, E., \& Vázquez, M. (2013). Technical and economical evaluation of microbial transglutaminase production on enzymatic hydrolysates of potato (Solanum tuberosum). Cyta-Journal of Food. Advance online publication. doi:10.1080/19476337.2012.736414

Ikura, K., Kometani, T., Yoshikawa, M., Sasaki, R., \& Chiba, H. (1980). Cross-linking of casein components by transglutaminase. Agricultural and Biological Chemistry, 44, 1567-1573.

Jaros, D., Partschefeld, C., Henle, T., \& Rohm, H. (2006). Transglutaminase in dairy products: Chemistry, physics, applications. Journal of Texture Studies, 37, 113-155.

Junqua, M., Duran, R., Gañiste, C., \& Goulas, P. (1997). Optimization of microbial transglutaminase production using experimental designs. Applied Microbiology \& Biotechnology, 48, 730-734.

Kampfer, P., Kroppenstedt, R. M., \& Dott, W. (1991). A numerical classification of the genera Streptomyces and Streptoverticillium using miniaturized physiological tests. Journal of General Microbiology, 137, 1831-1891.
Kuraishi, C., Sakamoto, J., Yamazaki, K., Susa, Y, Kuhara, C., \& Soeda, T. (1997). Production of restructured meat using microbial transglutaminase without salt or cooking. Journal of Food Science, 3, 488-515.

Lilley, G. R., Skill, J., Griffin, M. \& Bonner, P. L. B. (1998). Detection of $\mathrm{Ca}^{2+}$-dependent transglutaminase activity in root and leaf tissue of monocotyledonous and dicotyledonous plants. Plant Physiology, 117, $1115-1123$.

Motoki, M. (1989). Purification and characteristics of a novel transglutaminase derived from microorganisms. Agricultural and Biological Chemistry, 53, 2613-2617.

Motoki, M., Nio, N., \& Takinami, K. (1984). Functional properties of food proteins polymerized by transglutaminase. Agricultural and Biological Chemistry, 48, 1257-1261.

Motoki, M., \& Seguro, K. (1998). Transglutaminase and its use for food processing. Trends in Food Science \& Technology, 9, 204-210.

Nagy, V., \& Szakacs, G. (2008). Production of transglutaminase by Streptomyces isolates in solid-state fermentation. Letters in Applied Microbiology, 47, 122-127.

Portilla-Rivera, O. M., Telléz-Luis, S. J., Ramírez, J. A., \& Vázquez, M. (2009). Production of microbial transglutaminase on media made from sugar cane molasses and glycerol. Food Technology and Biotechnology, 47, 19-26.

Sarafeddinov, A., Arif, A., Peters, A., \& Fuchsbauer, H. L. (2011). A novel transglutaminase substrate from Streptomyces mobaraensis inhibiting papain-like cysteine proteases. Journal of Microbiology and Biotechnology, 21, 617-626.

Téllez-Luis, S. J., González-Cabriales, J. J., Ramírez, J. A., \& Vázquez, M. (2004). Production of transglutaminase by Streptoverticillium ladakanum NRLL-3191 grown on media made from hydrolysates of sorghum straw. Food Technology and Biotechnology, 42, 1-4

Téllez-Luis, S. J., Ramírez, J. A., \& Vázquez. M. (2004). Production of transglutaminase by Streptoverticillium ladakanum NRLL-3191 using glycerol as carbon source. Food Technology and Biotechnology, 42, 75-81.

Yasueda, H., Nakanishi, K., Kuzumaza, Y., Nagase, K., Motoki, M., \& Matsui, H. (1995). Tissue-type transglutaminase from red sea bream (Pagrus major). Sequence analysis of the cDNA and functional expression in Escherichia coli. European Journal of Biochemistry, $232,411-419$

Yokoyama, K., Nio, N., \& Kikuchi, Y. (2004). Properties and applications of microbial transglutaminase. Applied Microbiology and Biotechnology, 64, 447-454.

Wang, Y., Yu, L., \& Wei, X. (2012). Monosaccharide composition and bioactivity of tea flower polysaccharides obtained by ethanol fractional precipitation and stepwise precipitation. Cyta-Journal of Food, $10,1-4$. 